University of Nebraska - Lincoln

DigitalCommons@University of Nebraska - Lincoln

Faculty Publications from the Harold W. Manter Laboratory of Parasitology

6-1999

\title{
Scyphophyllidium uruguayense n. sp. (Eucestoda: Tetraphyllidea) in Mustelus mento (Cope, 1877) (Chondrichthyes: Carcharhiniformes: Triakidae) from La Paloma, Uruguay
}

\author{
Daniel R. Brooks \\ University of Toronto,dnlbrooks@gmail.com \\ Fernando Marques \\ University of Toronto \\ Carla Perroni \\ Universidad de la Republica (Montevideo, Uruguay) \\ Corina Sidagis \\ Universidad de la Republica (Montevideo, Uruguay)
}

Follow this and additional works at: https://digitalcommons.unl.edu/parasitologyfacpubs

Part of the Parasitology Commons

Brooks, Daniel R.; Marques, Fernando; Perroni, Carla; and Sidagis, Corina, "Scyphophyllidium uruguayense n. sp. (Eucestoda: Tetraphyllidea) in Mustelus mento (Cope, 1877) (Chondrichthyes: Carcharhiniformes: Triakidae) from La Paloma, Uruguay" (1999). Faculty Publications from the Harold W. Manter Laboratory of Parasitology. 201.

https://digitalcommons.unl.edu/parasitologyfacpubs/201

This Article is brought to you for free and open access by the Parasitology, Harold W. Manter Laboratory of at DigitalCommons@University of Nebraska - Lincoln. It has been accepted for inclusion in Faculty Publications from the Harold W. Manter Laboratory of Parasitology by an authorized administrator of DigitalCommons@University of Nebraska - Lincoln. 


\title{
SCYPHOPHYLLIDIUM URUGUAYENSE N. SP. (EUCESTODA: TETRAPHYLLIDEA) IN MUSTELUS MENTO (COPE, 1877) (CHONDRICHTHYES: CARCHARHINIFORMES: TRIAKIDAE) FROM LA PALOMA, URUGUAY
}

\author{
Daniel R. Brooks, Fernando Marques, Carla Perroni ${ }^{\star}$, and Corina Sidagis ${ }^{*}$ \\ Centre for Comparative Biology \& Biodiversity, Department of Zoology, University of Toronto, Toronto, Ontario, Canada M5S $3 G 5$
}

\begin{abstract}
A new species of Scyphophyllidium inhabits Mustelus mento near La Paloma, Uruguay. It resembles Scyphophyllidium giganteum from the Atlantic Ocean and specimens identified as $S$. giganteum from California by having anapolytic strobilae 155-258 mm long, 250-300 craspedote proglottids, scoleces 1.2-1.4 mm wide, necks 34-41 mm long, immature and mature proglottids wider than long, gravid proglottids wider than long to longer than wide, genital pores averaging $28 \%$ of proglottid length from the anterior end, relatively flat ovaries with digitiform lobes reaching the lateralmost extent of the testicular field, vitellaria in 2 fields converging toward the proglottid midline, straight and short cirrus sacs, and postvaginal vas deferens. The bothridia of the new species have accessory bothridial suckers that are smaller than those of California specimens; European specimens reportedly lack accessory bothridial suckers. The new species possesses a uterine duct that joins the uterus at the level of the genital atrium and ventral osmoregulatory ducts medial rather than lateral to the dorsal ducts, an arrangement described for Californian but not European specimens. It differs from both European and Californian specimens by having longer cirri, more testes per proglottid, prominent scales covering the neck, and vaginae and uterine ducts coiled immediately preovarially. Pithophorus, Marsupiobothrium, and Scyphophyllidium may form a clade.
\end{abstract}

During an inventory of the parasites of Uruguayan elasmobranchs, 5 specimens of a previously undescribed species of tetraphyllidean cestode belonging to the poorly known Scyphophyllidium Woodland, 1927 were collected from the spiral valve of 1 of 5 specimens of Mustelus mento (Cope, 1877) examined. In this paper we describe the new species, discuss the status of specimens assigned to Scyphophyllidium, and examine its possible phylogenetic affinities.

\section{MATERIALS AND METHODS}

Sharks were collected by commercial fishermen using bag seines in July 1993 along the coast of La Paloma, Uruguay. Cestodes were relaxed in sea water, killed in a relaxed condition with hot water, fixed immediately with alcohol-formalin-acetic acid (AFA), and stored in $70 \%$ ethanol. Whole mounts were stained with Mayer's hematoxylin. Serial cross sections of proglottids cut $7 \mu \mathrm{m}$ thick were stained with Mayer's hematoxylin and counterstained with eosin. Whole mounts and cross sections were mounted in Canada balsam. Scanning electron microscopy preparations were made using a standard dehydration, fixed in $1 \%$ osmium tetroxide, and processed in Peldri II (Pelco International, Riverdale, California) prior to sputter coating with gold. Specimens were examined with a Hitachi S-2500 scanning electron microscope. All measurements are in microns unless otherwise noted. Measurements are given as ranges with mean value followed by sample size in parentheses. USNPC refers to the U.S. National Parasitological Collection, Beltsville, Maryland and MHNG INV refers to Division of Invertebrates, Museum of Natural History, Geneva, Switzerland.

\section{DESCRIPTION}

\section{Scyphophyllidium uruguayense $\mathrm{n}$. sp.}

(Figs. 1a-c, 2a-c)

Measurements based on 4 complete and 1 incomplete specimens. Strobila weakly craspedote, anapolytic, $155-258 \mathrm{~mm}$ long, comprising 255-294 proglottids. Scolex 1.21-1.40 mm wide, comprising 4 globular bothridia and apical glandular mass of cells. Bothridia 572-890 ( $x=$ $731, \mathrm{n}=10)$ long by $572-731(x=652, \mathrm{n}=10)$ wide, with anterior but no posterior opening; pedicels extremely short. Apical accessory bothridial suckers 64-97 wide, positioned medially on anterior rim of

Received 10 February 1998; revised 2 December 1998; accepted 2 December 1998.

* Laboratorio de Zoologia de Invertebrados, Facultad de Ciencias, Universidad de la Republica, Tristan Narvaja 1674, 11200 Montevideo, Uruguay. each bothridium. Neck 34-41 mm long, covered with dense scales 32 63 wide, beginning at growth zone. Immature proglottids protandric, wider than long. Mature proglottids $0.64-1.18 \mathrm{~mm}$ long, $1.52-2.13 \mathrm{~mm}$ wide. Genital atrium indistinct; genital pores irregularly alternating in anterior $23-33 \%(x=28 \%, \mathrm{n}=20)$ of proglottid, closer to anterior end in younger proglottids. Cirrus sac elliptical to irregularly shaped, 349-464 ( $x=392, \mathrm{n}=20)$ long, 127-254 $(x=163, \mathrm{n}=20)$ wide, extending medially $19-23 \%(x=22 \%, \mathrm{n}=20)$ of proglottid width; containing spinose cirrus. Vas deferens convoluted; coils mediolateral to cirrus sac poral to midline of proglottid. Testes $19-41$ in diameter, 266-409 $(x=369, \mathrm{n}=24)$ in total number; 43-104 $(x=78, \mathrm{n}=24)$ preporally, 80-135 $(x=105, \mathrm{n}=24)$ postporally, 143-236 $(x=186$, $\mathrm{n}=24$ ) aporally. Ovary near posterior end of proglottid, bilobed with digitiform extensions in frontal view, $\mathrm{X}$-shaped in cross section; 1.18 $1.64 \mathrm{~mm}$ wide, extending $72-86 \%(x=79.5 \%, \mathrm{n}=20)$ of proglottid width. Vagina opening anterior to cirrus sac, extending medially to midproglottid anterior to vas deferens, then posteriorly, convoluted immediately anterior to ovarian isthmus; terminal portion expanded into distinct seminal receptacle. Vaginal sphincter glandular rather than muscular, extending length of cirrus sac. Seminal receptacle distinct. Mehlis' gland prominent, $127-165$ in diameter. Uterine duct extending anteriorly dorsal and poral to vagina, joining uterus near level of genital atrium, highly glandular, becoming expanded prior to appearance of eggs. Vitellaria extending entire length of proglottid laterally; follicles from each side of proglottid extending medially and dorsally $30-38 \%$ $(x=34 \%, \mathrm{n}=20)$ of proglottid width, beginning 51-95 from proglottid margin. Follicles reduced in number in area of terminal genitalia, crossing middle of cirrus sac dorsally, posterior end of cirrus sac ventrally; occasionally overlapping lateral ovarian digits. Vitelline follicles 32-64 $(x=48, \mathrm{n}=100)$ in diameter. Gravid proglottids $0.98-3.3 \mathrm{~mm}$ long, 1.36-2.51 mm wide; changing from wider than long to longer than wide. Genital atrium indistinct; genital pores irregularly alternating in anterior $23-34 \%(x=29 \%, \mathrm{n}=20)$ of proglottid, closer to anterior end in younger proglottids. Cirrus sac elliptical to irregularly shaped, 413-508 ( $x=467, \mathrm{n}=20)$ long, 222-273 $(x=249, \mathrm{n}=20)$ wide, extending medially $19-31 \%(x=23 \%, \mathrm{n}=20)$ of proglottid width; containing spinose cirrus. Vas deferens convoluted; coils medial to cirrus sac, poral to midline of proglottid. Testes degenerating. Ovary at posterior end of proglottid, bilobed with digitiform extensions in frontal view, $\mathrm{X}$-shaped in cross section; $1.12-1.91 \mathrm{~mm}$ wide, extending 62 $84 \%(x=77 \%, \mathrm{n}=20)$ of proglottid width. Uterus saccate, lacking diverticula but with occasional lateral folds; occupying available preovarian space. Vitellaria extending entire length of proglottid laterally; follicles from each side of proglottid extending medially, arching ventrally and dorsally $28-39 \%(x=33 \%, \mathrm{n}=100)$ of proglottid width, beginning 44-95 from proglottid margin. Vitelline follicles reduced in number in area of terminal genitalia, crossing middle of cirrus sac dorsally, posterior end of cirrus sac ventrally; occasionally overlapping 
A

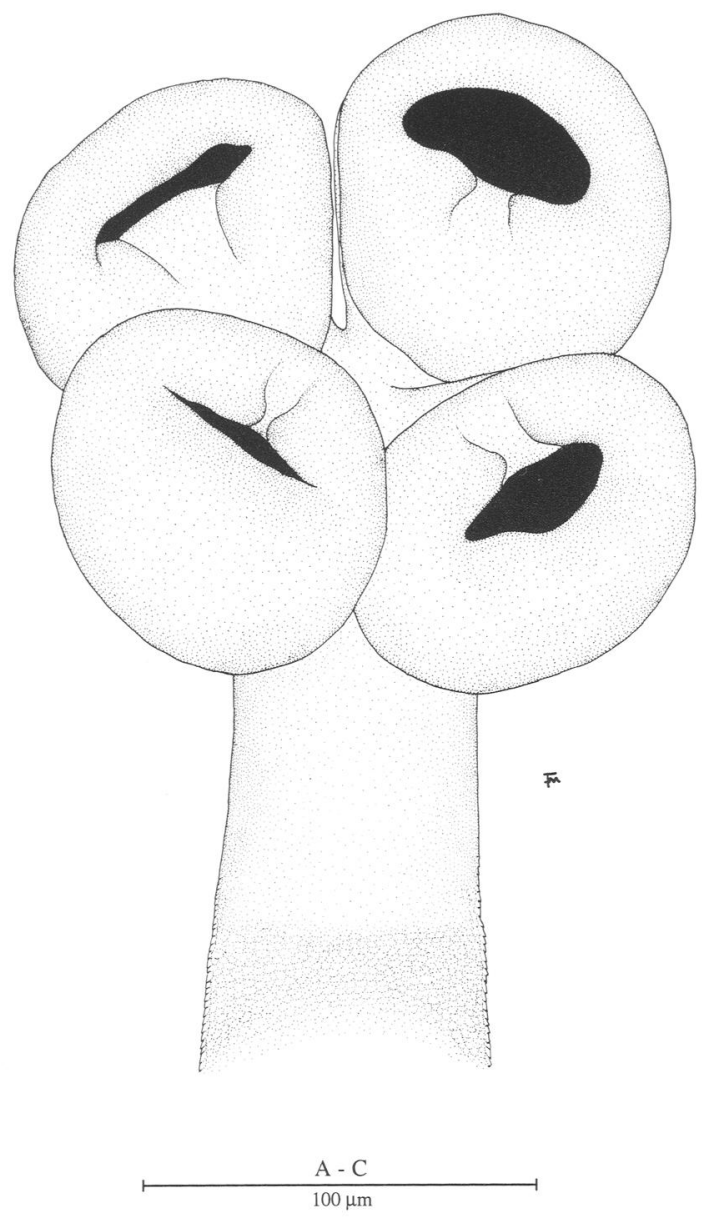

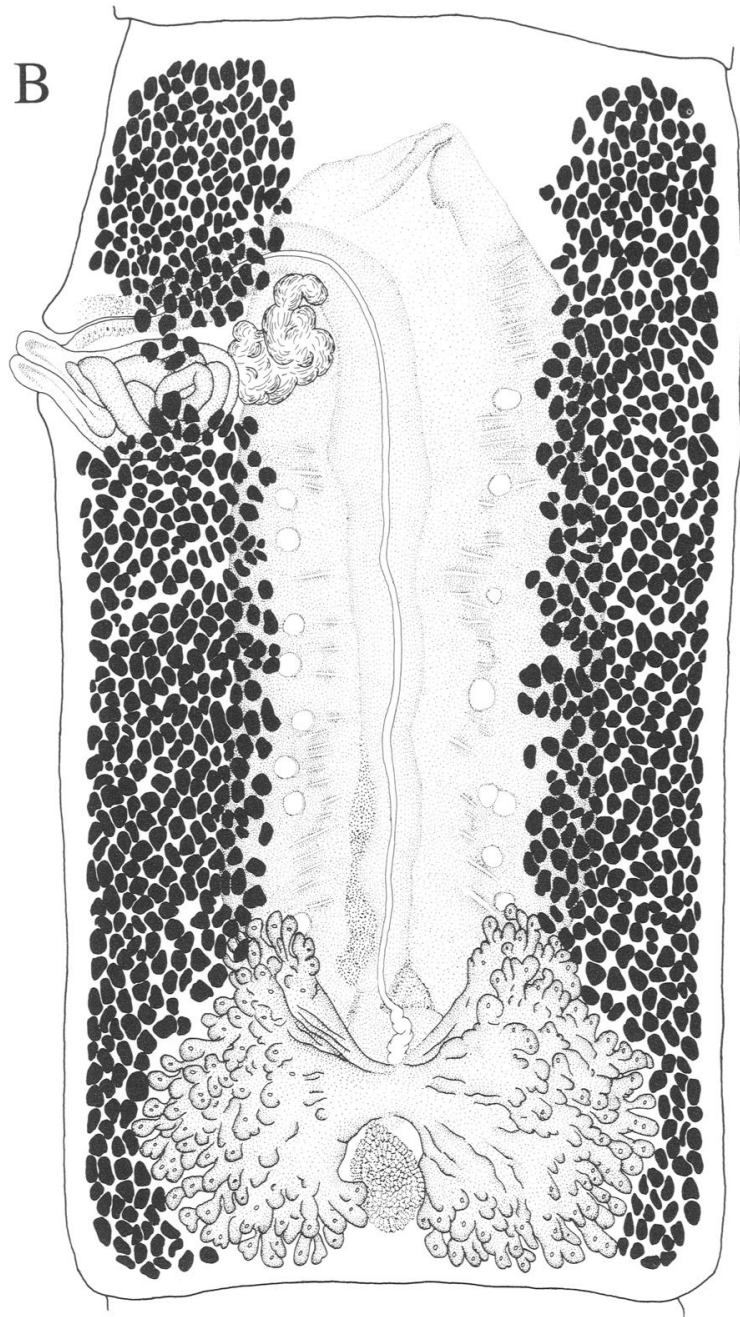

$\mathrm{C}$

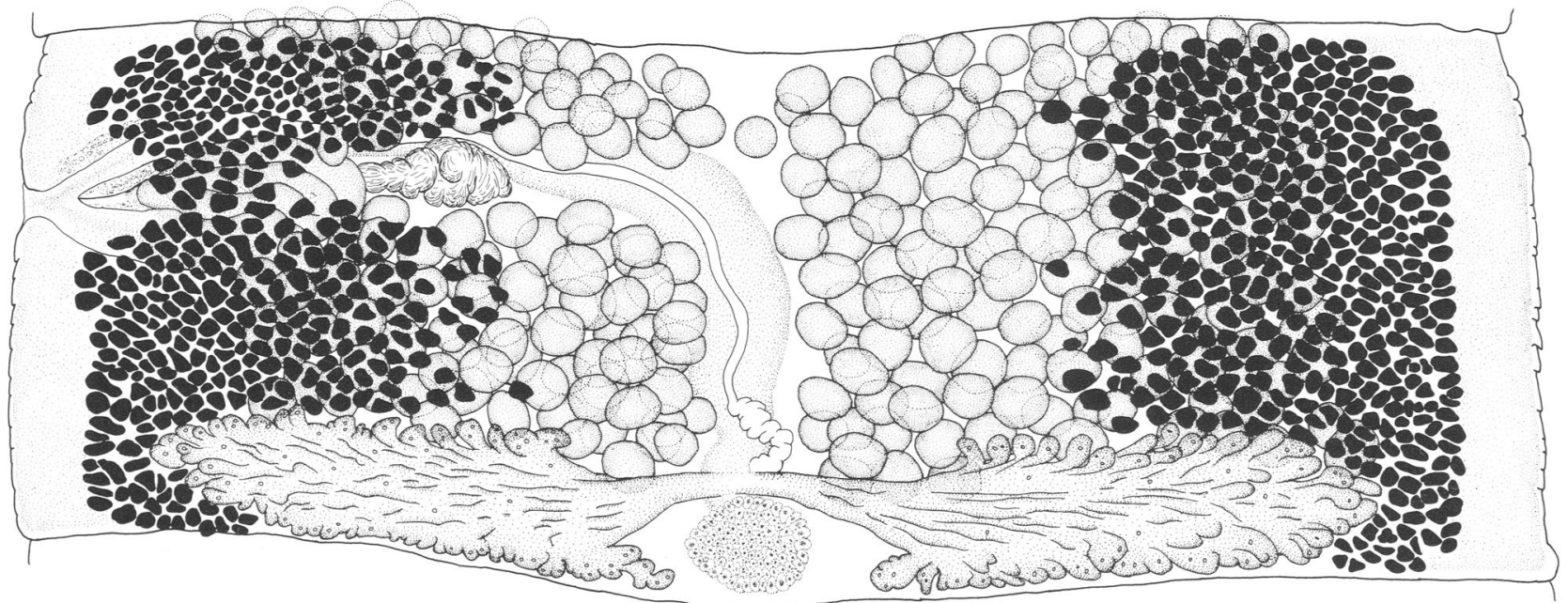

FIGURE 1. Scyphophyllidium uruguayense n. sp. A. Scolex. B. Gravid proglottid. C. Mature proglottid. 

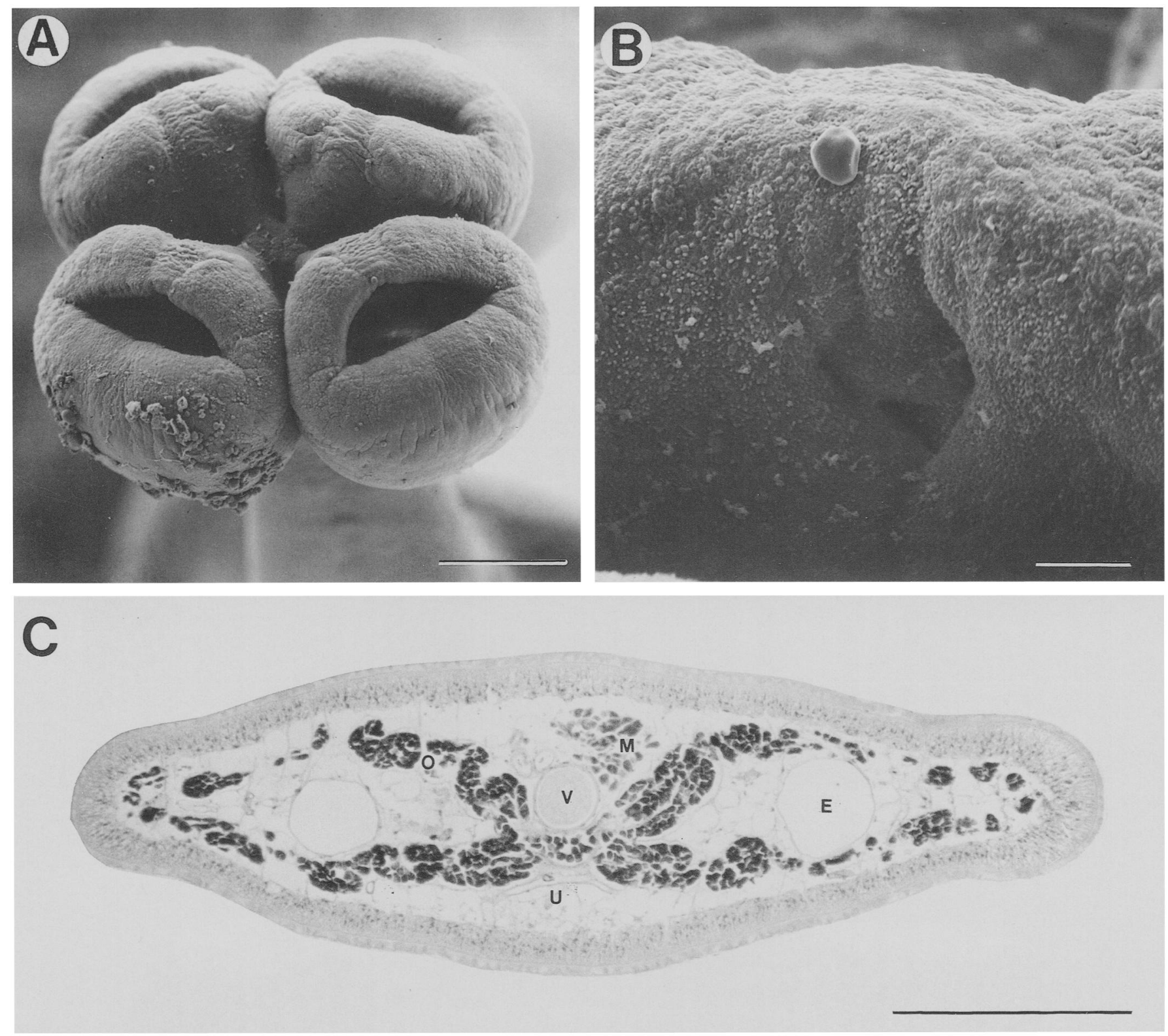

Figure 2. Scyphophyllidium uruguayense n. sp. A. Scanning electron micrograph of scolex. Scale bar $=250 \mu \mathrm{m}$. B. Scanning electron micrograph of anterior margin of bothridia showing apical accessory sucker. Scale bar $=250 \mu \mathrm{m}$. C. Cross section of mature proglottid through ootype region, showing excretory duct (e), Mehlis' gland (m), X-shaped ovary (o), uterus (u), and vagina (v). Scale bar $=100 \mu \mathrm{m}$.

lateral ovarian digits. Vitelline follicles $32-64$ in diameter. Ventral osmoregulatory ducts medial to dorsal ducts; terminal genitalia passing between osmoregulatory ducts.

\section{Taxonomic summary}

Type host: Mustelus mento (Cope, 1877) (Chondrichthyes: Carcharhiniformes: Triakidae).

Type locality: La Paloma, Uruguay.

Site of infection: Spiral valve.

Material deposited: Holotype MNHG INV 25448, paratypes MNHG INV 25449-50, USNPC No. 88542.

Etymology: The species is named for the country of Uruguay in whose waters it was first discovered.

\section{Remarks}

Scyphophyllidium is poorly known. Woodland (1927) proposed the genus after concluding that a specimen in the spiral valve of the shark
Galeus vulgaris (=Eugaleus galeus L.) from Plymouth, England, was conspecific with Anthobothrium giganteum van Beneden, 1858. Woodland characterized Scyphophyllidium primarily on the basis of its unique scolex morphology, comprising 4 cylindrical or globular bothridia, each having an anterior opening, which he interpreted as a sucker, and no posterior opening. Riser (1955) reported Scyphophyllidium giganteum in Galeorhinus zyopterus Jordan and Gilbert from coastal California and transferred Orygmatobothrium angustum Linton, 1901 to the genus, characterizing the bothridial morphology of Scyphophyllidium as "Phyllidia with muscular bothridial surfaces and an anterior accessory acetabulum," a vague characterization that includes most species of phyllobothriid tetraphyllideans. Riser (1955) reported that his specimens of $S$. giganteum had bothridia that were ". . boat-shaped when relaxed, suckerlike when contracted; auxiliary acetabulum $0.21-0.22 \mathrm{~mm}$ in diameter," and suggested that Woodland (1927) missed the accessory bothridial suckers because he did not examine live specimens. Euzet (1959) examined preserved specimens that he identified as S. giganteum, collected in E. galeus from Concarneau, France. Although Euzet 
referred to Riser's (1955) study in his publication, he made no mention of Riser's observations concerning $S$. giganteum. He reported that the bothridia were globular, in agreement with Woodland (1927) and Riser (1955), that the anterior openings of the bothridia were not accessory bothridial suckers, in agreement with Riser (1955), and that apical accessory bothridial suckers were lacking in the species. He also allocated Tetrabothrium maculatum (Olsson and Loennberg, 1889) to S. giganteum. Subsequent authors (e.g., Yamaguti, 1959; Schmidt, 1986; Euzet, 1994) have characterized the genus as having globular bothridial lacking both apical accessory bothridial suckers and posterior openings, excluding $O$. angustum from the genus.

Descriptions of the scolex and strobila dimensions and the proglottid morphology of the specimens identified as $S$. giganteum by Woodland (1927), Riser (1955), and Euzet (1957) agree in many ways with the specimens described herein from Uruguay. They are large: Woodland reported an incomplete strobila $95 \mathrm{~mm}$ long (he estimated a complete specimen would be $150 \mathrm{~mm}$ long), and Euzet reported specimens to be 100-120 mm long, whereas Riser reported specimens up to $384 \mathrm{~mm}$ long; specimens from Uruguay are $155-258 \mathrm{~mm}$ long. All 3 of these authors reported that the strobilae comprised several hundred proglottids; specimens from Uruguay comprise 250-300 proglottids. Euzet (1959) reported that his specimens were anapolytic, whereas Riser (1955) reported that his were apolytic; specimens from Uruguay are anapolytic. Woodland (1927) reported that his specimen had a scolex $1.9 \mathrm{~mm}$ wide, whereas Riser (1955) reported scoleces $1.32-1.45 \mathrm{~mm}$ wide, and Euzet (1959) reported scoleces 1.0-1.2 mm wide; the Uruguayan specimens have scoleces $1.2-1.4 \mathrm{~mm}$ wide. Woodland (1927) and Euzet (1959) reported neck lengths of more than $30 \mathrm{~mm}$ and 25 $30 \mathrm{~mm}$, respectively, whereas Riser (1955) did not list neck length for his specimens; Uruguayan specimens have necks $34-41 \mathrm{~mm}$ long. Both of these authors described their specimens as being acraspedote, whereas the specimens from Uruguay are slightly, but distinctly, craspedote. In agreement with the specimens from Uruguay, European and Californian specimens have been described as having immature and mature proglottids that are wider than long, and gravid proglottids that are wider than long to longer than wide. The genital pore position was listed by Riser (1955) and by Euzet (1959) as being in the anterior $1 / 3$ of the proglottid; specimens from Uruguay have genital pores averaging $28 \%$ of proglottid length from the anterior end. In all cases, including the specimens from Uruguay, the ovary is described or figured as relatively flat with digitiform lobes extending laterally to the lateralmost extent of the testicular field, and vitellaria are described as comprising 2 lateral fields converging toward the midline of the proglottid both dorsally and ventrally. The cirrus sac is depicted as straight and relatively short (occupying approximately $20 \%$ of the proglottid width), with the vas deferens not extending anterior to the vagina; this latter trait is uncommon but not unique among tetraphyllideans. It also occurs, for example, in Escherbothrium molinae Berman and Brooks, 1994, Phyllobothrium lactuca van Beneden, 1850 and Phyllobothrium thridax van Beneden, 1850, Crossobothrium longicolle (Molin, 1858) Euzet, 1959 and Crossobothrium triacis (Yamaguti, 1952) Euzet, 1959, and Dinobothrium septaria van Beneden, 1889.

Our observations on living and preserved material indicate that the bothridia of specimens from Uruguay are globular even when relaxed and never boat-shaped, with an anterior opening but no posterior opening, agreeing with descriptions by Woodland (1927) and Euzet (1959) and contrasting with the description by Riser (1959), and that an accessory bothridial sucker $64-97 \mu \mathrm{m}$ in diameter is present on each bothridium in contrast with suckers of $210-220 \mu \mathrm{m}$ in diameter reported by Riser (1955) and of suckers lacking as reported by Woodland (1927) and Euzet (1959). We thus place the specimens from Uruguay in Scyphophyllidium, with the proviso that accessory bothridial suckers may be present in all species of the genus. We also agree that $O$. angustum Linton, 1901 is not a member of Scyphophyllidium.

Specimens from Uruguay have cirrus sacs averaging $392 \mu \mathrm{m}$ long in mature proglottids and $467 \mu \mathrm{m}$ long in gravid proglottids, somewhat larger than those reported by Euzet (1959), who stated that the cirrus sacs of his specimens averaged $350 \mu \mathrm{m}$ in length and were much larger than those reported by Riser (1955), who stated that the cirrus sacs of his specimens averaged $260 \mu \mathrm{m}$ in length. Zamparo et al. (1999) recently noted that maximum cirrus sac length is a better character than average cirrus sac length, but not all authors have reported more than an average value. Woodland (1927) and Riser (1955) were not specific about the number of testes per progottid in their specimens, the latter stating that his had "several hundred" testes. Euzet (1959) stated that his specimens had 250-300 testes per proglottid, with an average of 90 postporal testes. Specimens from Uruguay have 266-409 testes per proglottid, averaging 368, and have an average of 105 postporal testes. Euzet's (1959) figure suggests a smaller number of preporal and aporal testes than exhibited by the specimens from Uruguay. The uterine duct in specimens from Uruguay is highly glandular and becomes expanded and saccate in late mature and gravid proglottids, extending anteriorly from the ootype poral to the vagina and entering the uterus at the level of the genital atrium, rather than entering the uterus posterior to the level of the genital pore as in most tetraphyllideans. Riser described the same morphology for his specimens from California. Euzet did not describe or figure any unusual structure of the uterine duct, reporting the uterus of his specimens to be bipartite, with an anterior part and with an immediately preovarian part, the 2 parts being connected by a "portion etranglee" (Euzet, 1959: 60). This morphology differs from that exhibited by the specimens from Uruguay. Riser reported that the specimens he identified as $S$. giganteum had ventral osmoregulatory ducts medial to the dorsal ducts; this is the reverse of the condition found in most tetraphyllideans. Our specimens from Uruguay exhibit this same unusual feature. Euzet did not describe the configuration of the osmoregulatory ducts in his specimens. The specimens from Uruguay exhibit 2 traits not described or figured by Woodland (1927), Riser (1955), or Euzet (1959). First, they possess prominent scales 32-63 $\mu \mathrm{m}$ wide covering the surface of the neck beginning at the point that the growth zone can be differentiated. Second, the vagina and uterine duct are highly coiled immediately anterior to the ovarian isthmus.

The descriptions by Woodland (1927), Riser (1955), and Euzet (1959) are incomplete in many ways. Given the disparity in geography and hosts, however, we think it likely that the European material, Riser's specimens, and the specimens from Uruguay represent 3 separate species. The specimens from Uruguay are diagnosably distinct based on the descriptions by Woodland (1927), Riser (1955), and Euzet (1959); we have thus assigned them to a separate species, $S$. uruguayense. We were unable to obtain any of the specimens examined by the latter author for study; Riser (1955) deposited specimens of most of the species he reported in his study in the U.S. National Parasite Collection but neglected to deposit specimens of Scyphophyllidium, and his personal collection is not currently available. Re-examination of this material, supplemented by new collections, is essential. Those workers in possession of such material should be make it available for study by a wider range of taxonomists.

\section{DISCUSSION}

At least 2 other poorly known genera of phyllobothriids share apparent apomorphic similarities with Scyphophyllidium. Marsupiobothrium Yamaguti, 1952 has bothridia shaped like pyriform sacs with anterior openings only and with a sphincter-like muscular "lip" surrounding the anterior opening and submarginal accessory suckers at the anterior end of the bothridia (Yamaguti, 1952) (which we interpret as homologous with the apical accessory bothridial suckers of other tetraphyllideans). The genus includes the type species Marsupiobothrium alopias Yamaguti, 1952 in Alopias vulpinus (Bonnaterre) and Marsupiobothrium forte (Woodland, 1924) Yamaguti, 1952 in Cestracion zygaena from Woods Hole, Massachusetts, which is known only from immature specimens. The bothridial openings are much larger than in $S$. uruguayense or European specimens of $S$. giganteum and might be described as "boatlike" when relaxed, similar to the specimens that in Riser's (1955) description of specimens he identified as S. giganteum. Pithophorus Southwell, 1925 is characterized by cylindrical or globular bothridia with both posterior and anterior openings; at least 1 species, Pithophorus vulpeculae Yamaguti, 1952, has accessory suckers (Yamaguti, 1952). The genus contains 5 nominal species, the type species Pithophorus tetraglobus Southwell, 1925 in Rhyn- 
chobatus djeddensis from Sri Lanka, P. vulpeculae in Vulpecula marina from Japan, Pithophorus musculosus Subhapradha, 1955 in Carcharias acutus Ruppell, Carcharias limbatus Müller and Henle, Carcharias walbeehmi Bleaker and $R$. djeddensis from the Madras coast of India, Pithophorus pakistanensis Zaidi and Khan, 1976 in Chiloscyllium indicum (Gmelin) from near Karachi, Pakistan, and Pithophorus yamagutii Shinde, 1978 in Scoliodon sp. from the west coast of India.

All these taxa need to be re-examined to determine appropriate generic groupings. Species assigned to all 3 genera have bothridia that are cylindrical in shape, presumably derived by fusion of the bothridial margins of a generalized phyllobothriid condition. If the initial condition were one in which there were openings at both ends, as exhibited by Pithophorus spp., closure of the posterior opening might be a synapomorphy linking $S c y$ phophyllidium and Marsupiobothrium as sister groups. The case for that sister group relationship is strengthened by the observation that the members of those 2 genera have the highest numbers of testes per proglottid in the group: $M$. alopias has 150-180 and Scyphophyllidium spp. have 250-409; Pithophorus tetraglobus, however, has 130-170. The liplike structure of the muscular anterior opening of the bothridia in Marsupiobothrium might serve as an autapomorphy supporting the monophyly of that genus, but Pithophorus musculosus Subhapradha, 1955 reportedly has bothridia bounded by 2 muscular pads at the anterior opening (Subhapradha, 1955). If those pads are homologous with the sphincter-like muscles surrounding the anterior opening of the bothridia of Marsupiobothrium spp., they might provide evidence that $P$. musculosus is more closely related to Marsupiobothrium and Scyphophyllidium than to other species of Pithophorus. Pithophorus musculosus, M. alopias, and Scyphophyllidium spp. exhibit vasa deferentia that do not extend medial or anterior to the vagina (Yamaguti, 1952; Subhapradha, 1955), further strengthening this hypothesis. Scyphophyllidium differs from Pithophorus and Marsupiobothrium by having vitellaria in multifollicle fields rather than single rows, a trait that could serve as an autapomorphy supporting the monophyly of Scyphophyllidium, although this trait is present in other tetraphyllidean groups as well. The presence of accessory bothridial suckers in at least some Scyphophyllidium spp., P. vulpeculae Yamaguti, 1952, and Marsupiobothrium spp. represents a persistent plesiomorphic trait and thus is not useful for determining phylogenetic relationships. If Pithophorus tetraglobatus, $P$. yamagutii, $P$. pakistanensis, and $P$. musculosus, plus $S$. giganteum sensu Euzet, 1959 all lack such suckers, their absence would therefore represent at least 3 independent losses.

\section{ACKNOWLEDGMENTS}

We thank Reva Berman, Norma Hollebeke, and Barbara Holcman for field and technical assistance. We also thank Eric Hoberg, U.S. National Parasite Collection, for assistance in finding some of the pertinent literature for this study. This study was funded by operating grant A7696 from the National Science and Engineering Council of Canada (NSERC) to D.R.B.

\section{LITERATURE CITED}

EuZET, L. 1959. Recherches sur les cestodes tetraphyllides des selaciens des cotes de France. Theses presentees a la faculte des Sciences de Montpellier pour obtenir le grade de docteur es Sciences Naturelles, Montpellier, France, 263 p.

- 1994. Order Tetraphyllidea. In Keys to the cestode parasites of vertebrates, L. F. Khalil, A. Jones, and R. A. Bray (eds.). CAB International, Saint Alban's, U.K., p. 149-194.

RISER, N. W. 1955. Studies on the cestode parasites of sharks and skates. Journal of the Tennessee Academy of Science 30: 265-311.

SCHMIDT, G. D. 1986. CRC handbook of tapeworm identification. CRC Press, Boca Raton, Florida, 675 p.

SubHAPRADHA, C. K. 1955. Cestode parasites of fishes of Madras coast. Indian Journal of Helminthology 7: 41-132.

WoODLAND, W. N. F. 1927. A revised classification of the tetraphyllidean Cestoda, with descriptions of some Phyllobothriidae from Plymouth. Proceedings of the Zoological Society of London 3: 519-548.

YamaGuTI, S. 1952. Studies on the helminth fauna of Japan. Part 49. Cestodes of fishes, II. Acta Medicinae Okayama 8: 1-76.

- 1959. Systema Helminthum, Vol. II. The cestodes of vertebrates. Interscience Publishers, Inc., New York, New York, $860 \mathrm{p}$.

Zamparo, D., D. R. Brooks, And R. Barriga. 1999. Pararhinebothroides hobergi $\mathrm{n}$. gen. n. sp. (Eucestoda: Tetraphyllidea) in Urolophus tumbesensis (Chondrichthyes: Rajiformes) from coastal Ecuador. Journal of Parasitology 85: 534-539. 